\title{
RELAÇÃO AVOENGA: A RECIPROCIDADE DA PRESTAÇÃO DE ALIMENTOS E VISITAÇÃO
}

\author{
AVOENGA RELATIONSHIP: A RECIPROCITY OF RENDER FOOD AND \\ VISITATION
}

\section{Resumo}

Este estudo tem por objetivo analisar a reciprocidade da prestação de alimentos e do direito de visita entre avós e netos, a fim de demonstrar que são postulados que possuem fundamento e ampla presença no ordenamento jurídico e doutrinário brasileiro, encontrando-se inseridos no Direito de Família. Os avós, pelo ius sanguinis, têm obrigação alimentar subsidiária em relação aos netos e, por certo, possuem a faculdade legal de requerer alimentos junto a eles, pois satisfazer as necessidades básicas do familiar carente tornou-se uma obrigação jurídica para aquele que possui condições financeiras. $\mathrm{O}$ inadimplemento da obrigação alimentícia permite que a parte credora proponha a ação de execução de alimentos, obrigando o devedor a cumprir com sua obrigação sob pena de prisão civil. Outro ponto de destaque é o direito que os avós têm de visitar seus netos, bem como de serem visitados por eles. O contato entre avós e netos é via de mão dupla, onde se um tem obrigação alimentar, também tem o direito de convívio.

Palavras-chave: Direito de Família. Relação Avoenga. Alimentos. Visitação.

\begin{abstract}
The present Project aims to analyze the reciprocity in relation to food supply and the visiting right between grandparents and grandchildren, in order to demonstrate that they are elements that have foundation and broad presence in the Brazilian legal system and doctrine, finding itself inserted into the Family Law. The grandparents, for the ius sanguinis, have the subsidiary duty in relation to their grandsons and also have the legal right to require food from them, because satisfying the basic needs of the needy family member has became a legal obligation for those who have financial conditions. The breach of the food obligation allows
\end{abstract}


the creditor to propose the enforcement action, forcing the debtor to accomplish with its obligation under civil imprisonment. Furthermore, it will be discussed the grandparents' right of visiting their grandsons, as well as the right of being visited by them. The contact between grandparents and grandchildren is a two-way street: where there is a maintenance obligation, there is also the right of living together.

Keywords: Family Law. Grandparents and Grandchildren. Food. Visitation

\section{INTRODUÇÃO}

Os seres humanos se complementam na unidade familiar, que se repete por gerações, estabelecendo normas de convivência entre seus membros e regras de comportamento com o intuito de se preservar a instituição familiar e, principalmente, seu tronco ancestral, pois é aonde se encontram os ascendentes e descendentes, garantidores da continuidade existencial.

Dessa forma, percebe-se que a entidade familiar é e sempre foi o sustentáculo existencial do Estado, haja vista se tratar da base da sociedade e, de acordo com a história da humanidade, sem povo para governar, não existe governante. Por essa razão ela precisa estar estruturada de forma sólida para promover a dignidade da pessoa humana e o desenvolvimento da personalidade de seus membros, além de possuir proteção especial do Estado.

Os laços afetivos criados através da convivência, solidariedade e respeito entre os parentes são o motor da manutenção da entidade familiar. Muito se sabe a respeito da relação entre pais e filhos, quais os direitos e quais os deveres a rondam, pois são assuntos amplamente discutidos e mencionados no dia-a-dia.

Infelizmente, pouco se sabe a respeito da relação avoenga, devido ao fato da lei não se voltar diretamente aos membros de tal relação em primeiro plano, sendo o foco voltado sempre para genitores.

O conceito de família defendido por vários doutrinadores, de que a família é a instituição mantida pelo amor, afeto e solidariedade nem sempre condiz com a realidade de muitos indivíduos. Pais rígidos que privam seus filhos do convívio familiar, filhos que desrespeitam os familiares, avós abandonados em asilos e pais que não reconhecem o vínculo sanguíneo e deixam sua prole à mercê da sorte são meramente exemplos de casos do dia-a-dia familiar. 
Assim, existem várias circunstâncias cotidianas que os netos desconhecem, inclusive sobre o direito de pleitear alimentos aos seus avós, diante da impossibilidade, total ou parcial, de seus genitores. Na mesma posição, vários avós, idosos em sua maioria, passam por dificuldades, principalmente decorrentes da idade, sem sequer possuírem o conhecimento de que podem requisitar judicialmente o amparo assistencial e alimentício aos descendentes.

Há casos, principalmente após a ruptura conjugal, em que os avós, por parte do genitor não-guardião, são proibidos de verem os netos pelo genitor guardião, pois este acha lógico vedar, ao seu bel-prazer, o direito de visita dos avós, ferindo os laços afetivos construídos entre as partes.

Dessa forma, o presente trabalho pretende expor e analisar a relação avoenga no que concerne ao direito-dever recíproco de prestar alimentos, bem como ao direito dos avós e netos se visitarem mutuamente nos casos de desfazimento da relação conjugal pelos genitores, pois nem sempre os membros da família entendem a necessidade da convivência e da prestação alimentícia, colocando empecilhos e interesses particulares para prejudicar a aplicação dos direitos e deveres personalíssimos oriundos do ius sanguinis e protegidos pela Constituição Federal.

\section{BREVE ABORDAGEM SOBRE OS DIREITOS DA PERSONALIDADE}

Ao tratar da relação entre avós e netos, importante se faz ressaltar quais direitos rondam tal laço afetivo, como surgiram e porque eles são tão importantes para a sua manutenção. Dessa forma, uma breve análise sobre os direitos da personalidade é imprescindível, pois são eles que norteiam a vida em sociedade e é a partir deles que a teia de novos direitos se constitui.

Assim que os homens passaram a viver em grupos, formando as primeiras comunidades, começaram a perceber que seria necessário criar mecanismos para regular as condutas que pusessem em risco a própria continuidade da existência humana. Destarte, quando há a superação da utilização da força física, da força bruta, a qual sobrepuja o mais fraco em suas vontades e da qual se valiam os homens das cavernas, surge o reconhecimento dos direitos. Dessa forma, cansados da opressão e de resolver seus conflitos pela violência, o homem viu-se forçado a adotar regras de conduta que impusessem o respeito aos direitos daqueles com quem ele interagia nas comunidades, o que acabava por proteger seus interesses individuais. 
Foi assim que o homem, por depender de suas relações sociais, entendeu que a anarquia e o caos precisavam ser evitados ao máximo. E a consecução de tal desiderato vem se tornando possível por meio do Direito, que fixa regras coercíveis de conduta e que reconhece os direitos fundamentais do próximo.

E é exatamente ao reconhecer tais direitos que começou a surgir no bojo da sociedade a idéia de igualdade. Ao entender que os direitos reconhecidos ao outro beneficiariam também a ele próprio, o homem começou a desenvolver a idéia dos direitos humanos, dos quais se originam os direitos da personalidade.

De acordo com Gonçalves (2009, p. 153), ratificando o entendimento de Azevedo (2008, p. 40), os direitos da personalidade são prerrogativas individuais, inerentes à pessoa humana, aos poucos reconhecidas pela doutrina e pelo ordenamento jurídico, bem como protegidas pela jurisprudência, assumindo característica de direito inalienável, fazendo por merecer a proteção legal.

Analisando os fundamentos dos direitos da personalidade, a corrente majoritária, nacional e internacional, defende a sua existência, dividindo-os em duas categorias: os inatos e os adquiridos. Os primeiros, conforme aduz a antiga doutrina da escola do Direito Natural, são decorrentes da realidade psicofísica, atinentes ao ser humano, por sua própria natureza, cabendo ao Estado apenas reconhecê-los e sancioná-los no plano do direito positivo, e não criá-los. Já a categoria dos direitos da personalidade adquiridos são aqueles decorrentes de um status individual e existem graças a um direito positivo que lhes conferiu validade.

No que tange às características, ninguém melhor para explicá-las de forma sucinta e completa do que Azevedo (2008, p. 41), quando afirma que

[...] os doutrinadores têm-nos declinado, concluindo que os direitos da personalidade
são, em princípio, direitos subjetivos privados, porque, respeitando as pessoas,
como simples seres humanos, propõem-se a lhes assegurar a satisfação do próprio
ser, físico e espiritual; são direitos não patrimoniais, extrapatrimoniais,
tipicamente pessoais, porque não visam a uma utilidade de ordem econômica e
financeira; são direitos originários ou inatos, porque se adquirem, naturalmente,
sem o concurso de formalidades externas; são direitos absolutos ou de exclusão,
visto que são oponíveis erga omnes; são direitos intransmissíveis, pois que
inerentes à pessoa de seu titular, que deles, assim, não pode dispor; são direitos
irrenunciáveis, porque não podem ser desprezados ou destruídos, sendo, dessa
forma, insuscetíveis de rejeição; e são direitos imprescritíveis, porque podem ser
exercidos a qualquer tempo. Registre-se, nesse passo, que somente a partir de 1988, com o advento da Constituição Federal, a legislação brasileira passou a adotar uma postura mais protetora dos direitos personalíssimos, com seus fundamentos e caracteres. 
No âmbito do direito privado, tendo em vista a defasagem do Código Civil de 1916 em relação ao novo texto constitucional (que não previa, em capítulo próprio, essa espécie de direitos fundamentais da pessoa), a evolução da proteção de tais direitos mostrou-se bastante atrasada, sendo tutelada por leis especiais, como foi o caso do Estatuto da Criança e do Adolescente, Lei 8.069 de 13 de julho de 1990, até se chegar ao Código Civil de 2002.

O tratamento dessa matéria veio, assim, a ser cuidado do artigo 11 ao 21, englobados em um único capítulo do Código Civil. Mas é importante ressaltar que, em face da nãolimitação dos direitos da personalidade, não se trata de um rol taxativo e sim meramente exemplificativo, mencionando expressamente apenas alguns direitos.

Todos os direitos, na medida em que conferem conteúdo à personalidade, poderiam se chamar direitos da personalidade. Existem certos direitos sem os quais a personalidade restaria incompleta, direitos sem os quais todos os outros direitos subjetivos perderiam todo o interesse para o indivíduo, a pessoa não existiria como tal.

O sistema de proteção jurídica dos direitos da personalidade funda-se sobre duas cláusulas gerais, constantes no inciso III do artigo $1^{\circ}$ da Constituição Federal e no caput do artigo 12 do Código Civil, ambos in verbis:

\footnotetext{
Art. $1^{\circ}$. A República Federativa do Brasil, formada pela união indissolúvel dos Estados e Municípios e do Distrito Federal, constituem-se em Estado Democrático de Direito e tem como fundamentos:

[...]

III - a dignidade da pessoa humana;

[...].

Art. 12. Pode-se exigir que cesse a ameaça, ou a lesão, a direito da personalidade, e reclamar perdas e danos, sem prejuízo de outras sanções previstas em lei.
}

Assim, infere-se que a dignidade da pessoa humana é o objeto, ao final, tutelado pelos direitos da personalidade.

Na verdade, é impossível falar em direitos da personalidade sem se falar no Princípio da Dignidade da Pessoa Humana, pois ele é um motor de impulsão de todo o sistema jurídico. Tal princípio vem com o intuito de garantir a integridade física e psíquica, garantir a liberdade e igualdade e assegurar pressupostos materiais mínimos para uma sobrevivência digna.

A preservação dos mais íntimos sentimentos deve ser respeitada, porque eles transcendem a pessoa, atingem de modo intenso cada ser humano e, se o fim buscado é o de respeitar a igualdade entre os seres humanos, nada pode ocorrer que estremeça a proteção deste direito, seja para qual pessoa for, sendo incluídos, portanto, os membros da relação avoenga. 
De tal princípio decorre, ainda, o direito à alimentação, que se enquadraria de forma geral nos direitos da personalidade. Apesar de não ser expressamente previsto na Constituição, ele decorre, também, diretamente de outros princípios basilares do ordenamento jurídico, como do direito à vida plena e à saúde, conforme se verá a seguir.

\section{DO DIREITO A ALIMENTOS}

A unidade familiar vem alcançando uma compreensão sócio-afetiva, deixando de ser compreendida como mero núcleo reprodutivo e econômico, caminhando, portanto, rumo à adoção plena do princípio da dignidade humana em detrimento de valores meramente patrimoniais.

Os laços familiares tornam-se cada vez mais fortes e imprescindíveis ao desenvolvimento do indivíduo na sociedade, pois é no âmbito familiar que o homem aprende sobre a solidariedade, sobre o afeto, sobre a importância de se proteger seus membros, haja vista que é a família que existe em razão de seus componentes e não o contrário. Assim, surge a figura da afeição, que, nas palavras de Lisboa (2004, p. 57):

[...] é a ligação existente entre os membros da família por decorrência dos sentimentos que os unem. [...] A afeição é um sentimento que se tem em relação a determinada pessoa ou a algum bem. Afeiçoar-se significa identificar-ser, ter afeto, amizade ou amor. Os membros de uma família, em sua maioria, possuem laços de afeição, uns com os outros.

Mas, conforme o mesmo autor menciona em sua obra, as entidades familiares nem sempre são construídas por uma ligação afetiva. Há casos excepcionais em que ela não se verifica, pois uma pessoa não é obrigada a ter afeto por outra, mesmo que estejam vinculadas pelo parentesco.

O respeito, por sua vez, aparece como elemento inerente à solidariedade e que deve necessariamente se achar presente em qualquer relação familiar. Para Lisboa (2004, p.57), “respeito é, nesse sentido, a consideração ou importância que se dá a um membro da entidade familiar, mesmo quando o parentesco é colateral”.

A afeição e o respeito acabam assumindo papéis de vetores que indicam o dever de cooperação mútua entre os membros da família, para os fins de assistência imaterial e material. 
Assim, uma conclusão sucinta e inegável a que chegaram Farias e Rosenvald (2008, p. 585) é que:

[...] a família cumpre modernamente um papel funcionalizado, devendo, efetivamente, servir como ambiente propício para a promoção da dignidade e a realização da personalidade de seus membros, integrando sentimentos, esperanças e valores, servindo como alicerce fundamental para o alcance da felicidade.

Ao se aplicar o princípio vetor constitucional mencionado acima no âmbito dos alimentos, é fácil se deparar com o fato de que os alimentos tendem a proporcionar uma vida de acordo com a possibilidade do assistente e a necessidade do assistido, assumindo um caráter de assistência material.

Contudo, outros princípios basilares também estão presentes no momento de se mensurar os alimentos devidos, tais como a cooperação, a isonomia, a segurança e a justiça social, bem como a solidariedade. Todos eles juntos fazem com que os alimentos assumam uma função de garantidor da manutenção das pessoas ligadas por um vínculo de parentesco.

Ora, é bem verdade que, em perspectiva mais realista, nem sempre os laços familiares, construídos com afeto e respeito, tampouco os princípios resguardados pela Constituição Federal são suficientes para assegurar a cada indivíduo as condições necessárias para a manutenção de uma vida digna, em todas as suas formas.

Faz-se necessário a participação do Judiciário, pois ele é capaz de promover a efetivação dos direitos dos necessitados, obrigando os componentes do grupo familiar responsáveis a cumprirem com seus deveres, quais sejam prestar alimentos.

\subsection{Conceito de alimentos e sua natureza jurídica}

Importante se faz ressaltar que vários autores, ao formularem seus conceitos do que venham a ser os alimentos, de certo modo, acabaram alcançando a mesma definição, uns de forma mais abrangente que outros, mas nada que reste em divergências importantes a fim de incitar um debate doutrinário ou até mesmo um dissenso jurisprudencial.

Em concepção jurídica, os alimentos podem ser vistos como todos os meios necessários para se promover a manutenção do indivíduo, na busca da configuração plena de uma vida digna. Nesse contexto, Farias e Rosenvald (2008, p. 588) complementam afirmando 
que "é possível entender-se por alimentos o conjunto de meios materiais necessários para a existência das pessoas, sob o ponto de vista físico, psíquico e intelectual".

Aquela idéia restrita e desatualizada de que os alimentos contemplariam somente gastos com a alimentação não é aceita pela doutrina tampouco pela jurisprudência.

\begin{abstract}
Por óbvio, incluem nos alimentos tanto despesas ordinárias, como os gastos com alimentação, habitação, assistência médica, vestuário, educação, cultura e lazer, quanto as despesas extraordinárias, envolvendo, por exemplo, gastos em farmácias, vestuário escolar, provisão de livros educativos... Somente não estão alcançados os gastos supérfluos ou luxuosos e aqueloutros decorrentes de vícios pessoais (FARIAS; ROSENVALD, 2008, p. 588).
\end{abstract}

Nesse diapasão, percebe-se, portanto, que o conceito de alimentos é muito mais abrangente, significando a própria preservação da dignidade humana. O Código Civil, em seu artigo 1.694, informa que "podem os parentes, os cônjuges ou companheiros pedir uns aos outros os alimentos de que necessitem para viver de modo compatível com a sua condição social, inclusive para atender às necessidades de sua educação".

Essa "solicitação" de alimentos, em termos jurídicos, recebe a denominação de pensão alimentícia, ou seja, uma quantia em dinheiro destinada às despesas ordinárias e extraordinárias, conforme visto acima.

É possível, também, a prestação in natura dos alimentos, traduzida na entrega dos próprios bens destinados à sobrevivência e desenvolvimento do alimentado, como, por exemplo, a entrega de uma cesta básica ou o pagamento da mensalidade escolar da criança.

Contudo, tal critério pode despertar dúvidas acerca da qualidade dos bens fornecidos, pois deixa o alimentando restrito à vontade do alimentante. A ocorrência de tal fato está fazendo com que os juízes evitem aplicação in natura dos alimentos, optando por sua aplicação exclusivamente civil, que se consubstancia em verbas para a habitação, vestuário, educação, lazer, saúde e funeral.

No que concerne a natureza jurídica dos alimentos, é importante salientar que o tema não é pacífico, fruto de posições divergentes de três correntes doutrinárias.

A primeira posição doutrinária defende a natureza jurídica do direito à prestação de alimentos como direito pessoal sem caráter patrimonial. O alimentando não possuiria interesse econômico na prestação de alimentos, haja vista não objetivar a ampliação do seu acervo patrimonial, mas sim suprir o seu direito à vida digna, que é personalíssimo, promovendo a manutenção da sua integridade física, psíquica e intelectual. Funda-se, portanto, num conteúdo ético-social. 
Já a segunda corrente, atuando em um sentindo completamente oposto, entende os alimentos como um direito meramente patrimonial, retratado na prestação pecuniária, em que o caráter econômico do indivíduo é o foco principal da relação.

Por fim, a terceira corrente defende uma natureza mista e eclética dos alimentos, sendo a sua prestação um direito de conteúdo patrimonial e finalidade pessoal.

A divergência doutrinária está basicamente entre a primeira corrente e a última, sendo descartada a corrente que se funda no caráter meramente patrimonial dos alimentos.

Inegável é o conteúdo moral do socorro entre os membros do grupo familiar quando presente a necessidade, providência que interessa a toda sociedade. Daí decorre que, a obrigação alimentar advinda do parentesco, apesar de polêmica tanto no embate doutrinário quanto no jurisprudencial, pode se originar da lei, da vontade humana ou de uma sentença judicial.

\subsection{Principais características}

É natural que os alimentos estejam cercados de características peculiares que os diferenciam das demais relações obrigacionais comuns, pois se trata de uma relação voltada à manutenção da pessoa e sua dignidade humana, em que está presente o binômio necessidade do credor e possibilidade do devedor para a fixação da pensão.

Dessa forma, a primeira característica básica dos alimentos, da qual inclusive decorrem as demais, é que eles assumem um caráter personalíssimo. Diante do fato que os alimentos se destinam à subsistência do alimentando, preservando sua integridade física e psíquica, acabam por constituírem um direito pessoal, intransferível. Assim, para Farias e Rosenvald:

[...] o direito a alimentos não admite cessão onerosa ou gratuita, bem assim como não tolera compensação, com dívidas de que natureza for. De mais a mais, também será impenhorável o crédito alimentício e terá preferência de pagamento nos casos de concursos de credores.

Nesse contexto, extrai-se mais uma característica dos alimentos: são incessíveis. Os artigos 286 e 1.707, ambos do Código Civil, são bem explicativos, a ver:

Art. 286. O credor pode ceder o seu crédito, se a isso não se opuser a natureza da obrigação, a lei, ou a convenção com o devedor; a cláusula proibitiva da cessão não 
poderá ser oposta ao cessionário de boa-fé, se não constar do instrumento da obrigação.

Art. 1.707. Pode o credor não exercer, porém lhe é vedado renunciar o direito a alimentos, sendo o respectivo crédito insuscetível de cessão, compensação ou penhora.

No entanto, somente não pode ser cedido o direito a alimentos que ainda serão pleiteados. O crédito constituído por pensões alimentares vencidas é equiparado a outro qualquer, pois já está integrado ao patrimônio do alimentando, que logrou êxito em promover sua subsistência mesmo sem ter recebido os alimentos. Nessa hipótese o crédito alimentício pode ser cedido.

Analisando o artigo 1.707 transcrito acima, nota-se outra característica marcante dos alimentos. É inconcebível a penhora de um direito destinado à manutenção de uma pessoa e tal fato é protegido pelo inciso II do artigo 649 do Código de Processo Civil, ao dizer que "são absolutamente impenhoráveis as provisões de alimento e de combustível, necessárias à manutenção do devedor e de sua família durante um mês".

A última característica abordada pelo artigo 1.707 é a sua incompensabilidade, haja vista a obrigação alimentar não permitir o uso de tal instituto para extinguir as obrigações de forma indireta, conforme excetua o inciso II do artigo 373 do Código Civil, ao dizer que a diferença de causa nas dívidas não impede a compensação, exceto se uma delas se originar de alimentos.

\begin{abstract}
A regra, no entanto, não pode ganhar ares absolutos. É que, em certos casos, com o propósito de evitar o enriquecimento sem causa do credor que recebeu uma determinada parcela alimentícia a maior, é possível a compensação do valor pago indevidamente nas parcelas vincendas, de modo a obstar acréscimo patrimonial indevido. (FARIAS; ROSENVALD, 2008, p. 609)
\end{abstract}

Não há prazo extintivo para os alimentos, tornando-os imprescritíveis. Para Lisboa (2004, p. 65), “o direito a alimentos pode ser requerido a qualquer tempo, porém deve-se verificar no fato pretérito a existência do binômio necessidade do alimentando e possibilidade do alimentante". A partir do momento em que os alimentos foram fixados por decisão judicial, começará a fluir um prazo prescricional para a sua execução. Dessa forma, são passíveis de prescrição tão-somente as prestações vencidas e não pagas nos últimos dois anos, como reconhece o $\S 2^{\circ}$ do artigo 206 do Código Civil.

Outra importante característica dos alimentos é que eles são atuais, ou seja, são fixados com a indicação de um critério de correção de valor vigente à época de sua aplicação, 
como menciona o artigo 1.710 do Código Civil, ao afirmar que "as prestações alimentícias, de qualquer natureza, serão atualizadas segundo índice oficial regularmente estabelecido”.

Além do mais, a quantia paga a título de alimentos não pode ser restituída pelo alimentando, caracterizando a sua irrepetibilidade, haja vista terem sido fundamentais à sobrevivência do indivíduo. Importante ressaltar que não há distinção entre as espécies de alimentos, se eles são provisórios, definitivos ou ad litem. Para Farias e Rosenvald (2008, p. 606), "A irrepetibilidade alimentícia, enfim, sempre foi vista com dimensão praticamente absoluta, não se admitindo em qualquer hipótese a restituição do valor pago a título de alimentos", mesmo que venha a ser desconstituído o título que serviu de base para a sua configuração. Em outras palavras, ainda que a ação venha a ser julgada improcedente, não cabe a restituição dos alimentos, pois à época dos fatos, quem pagou, pagou uma dívida e não meramente realizou uma simples antecipação ou empréstimo.

Averbe-se, por oportuno, que somente quando ficar provado a absoluta desnecessidade do credor em receber os alimentos (ou seja, quando se demonstrar que o recebimento importou enriquecimento ilícito), demonstrada pelo alimentante em concreto, em via cognitiva ampla própria (ação autônoma), será admissível a restituição judicial (que alguns autores preferem denominar relatividade da irrepetibilidade). (FARIAS; ROSENVALD, 2008, p. 607)

Assim, é somente admitida a restituição judicial em casos especiais, respeitando a vedação do enriquecimento ilícito constante nos artigos 884 e 885 do Código Civil, transcritos a seguir:

Art. 884. Aquele que, sem justa causa, se enriquece à custa de outrem, será obrigado
a restituir o indevidamente auferido, feita a atualização dos valores monetários.
Parágrafo único. Se o enriquecimento tiver por objeto coisa determinada, quem a
recebeu é obrigado a restituí-la, e, se a coisa não mais subsistir, a restituição se fará
pelo valor do bem na época em que foi exigido. Art. 885. A restituição é devida, não só quando não tenha causa que justifique o enriquecimento, mas também se esta deixou de existir.

Através da regra da irrenunciabilidade, preserva-se a impossibilidade da renúncia aos alimentos, assumindo postura de direito fundamental, que poderão ser pleiteados ulteriormente, após se verificar os pressupostos legais. Contudo, tal característica atinge somente o direito a alimentos, não o seu exercício. O artigo 1.707 do Código Civil, já transcrito acima, permite ao credor escolher postular ou não em juízo, sendo tal atitude interpretada apenas como falta de exercício e não renúncia ao direito a alimentos em si. 
Uma polêmica gira em torno do assunto no que tange em favor de quem os alimentos são irrenunciáveis. A jurisprudência dominante do Superior Tribunal de Justiça entende que somente em relação aos incapazes tal característica é aplicada, permitindo somente a dispensa de se cobrar pensão alimentícia por determinado momento, sendo permitida a renúncia dos alimentos devidos em razão do casamento ou da união estável, a ver:

DIREITO CIVIL E PROCESSUAL CIVIL. FAMÍLIA. SEPARAÇÃO JUDICIAL. ACORDO HOMOLOGADO. CLÁUSULA DE RENÚNCIA DE ALIMENTOS. POSTERIOR AJUIZAMENTO DE AÇÃO DE ALIMENTOS POR EX-CÔNJUGE. A cláusula de renúncia a alimentos, constante em acordo de separação devidamente homologado, é válida e eficaz, não permitindo ao ex-cônjuge que renunciou a pretensão de ser pensionado ou voltar a pleitear o encargo. (STJ, Ac. Unân. $3^{\mathrm{a}}$ T., REsp. 701.902/SP, rel. Min. Fátima Nancy Andrighi, j. 15.9.05, DJU 3.10.05, p. 249).

Corroborando nesse sentindo, alguns doutrinadores, dentre eles Farias e Rosenvald (2008, p. 591), entendem que:

[...] não é razoável que um cônjuge ou companheiro venha a renunciar à prestação alimentícia no acordo de dissolução consensual da conjugalidade, criando no outro uma expectativa, e, posteriormente, de forma surpreendente, venha a pleitear os alimentos, com base em interpretação literal do texto legal. Trata-se de típica hipótese de Nemo venire contra fatcum proprium (proibição de comportamento contraditório), caracterizando um ato ilícito objetivo, também chamado de abuso de direito (CC, art. 187). [...] Enfim, é a consagração de que ninguém pode se opor a fato a que ele próprio deu causa. [...] Nesta ordem de idéias, é fácil concluir o acerto do entendimento jurisprudencial, corroborando da possibilidade de renúncia válida e eficaz ao direito de pleitear alimentos entre pessoas capazes, por criar em outrem determinada expectativa. Se a parte entende que pode precisar dos alimentos, deve resguardar para si o direito de pleiteá-los, não renunciando - o que é absolutamente possível. O que não se permite é criar uma expectativa e, depois, surpreender.

Assim sendo, infere-se que os alimentos somente são considerados irrenunciáveis quando se trata de incapazes no pólo ativo da ação e, que entre capazes, a renúncia é admitida vedando-se a cobrança posterior.

Alguns doutrinadores, como Dias (2009, p. 464, 468), abordam algumas características além das mencionadas até então, tais como a alternatividade, a periodicidade e a anterioridade.

\subsection{Sujeitos da obrigação alimentar}


Sob uma perspectiva genérica sobre os sujeitos da relação alimentícia, o artigo 1.694 da Codificação Reale traz a seguinte redação:

\begin{abstract}
Art. 1.694. Podem os parentes, os cônjuges ou companheiros pedir uns aos outros alimentos de que necessitem para viver de modo compatível com a sua condição social, inclusive para atender às necessidades de sua educação.

$\S 1^{\circ}$. Os alimentos devem ser fixados na proporção das necessidades do reclamante e dos recursos da pessoa obrigada.

$\S 2^{\circ}$. Os alimentos serão apenas os indispensáveis à subsistência, quando a situação de necessidade resultar de culpa de quem os pleiteia.
\end{abstract}

Assim, conforme Louzada (2008, p. 09), "Têm legitimidade para figurar nos pólos de uma ação alimentar, os sujeitos interligados por laços de parentesco, pelo casamento ou por união estável, nos termos do art. 1.694 do CC, assim como os companheiros de união homoafetiva”. Contudo, é inegável a existência de vários fatores que cercam tal obrigação, sendo relevante o estudo para a matéria.

As pessoas podem ser catalogadas em duas espécies: naturais e jurídicas, ambas sujeitos de direitos e obrigações. Todavia, tem-se, desde logo, que uma pessoa jurídica não necessita de alimentos, o que nos leva à óbvia conclusão que somente pessoas naturais podem ser sujeitos ativos do direito de alimentos e autores dessa postulação.

Regra geral, de acordo com o art. $2^{\circ}$ do Código Civil, a personalidade civil começa a partir do nascimento com vida, pois é nesse momento que surgem as necessidades básicas da vida humana. Do nascimento até a capacidade civil, a criança e o adolescente estarão sob a proteção legal de seus genitores e, em casos da não possibilidade destes, de tutor por eles nomeado ou daquele definido pelo art. 1731 do Código Civil, a seguir transcrito:

\footnotetext{
Art. 1.731. Em falta de tutor nomeado pelos pais incube a tutela aos parentes consangüíneos do menor, por esta ordem:

I - aos ascendentes, preferindo o de grau mais próximo ao mais remoto;

II - aos colaterais até o terceiro grau, preferindo os mais próximos aos mais remotos,

e, no mesmo grau, os mais velhos aos mais moços; em qualquer dos casos, o juiz escolherá entre eles o mais apto a exercer a tutela em benefício do menor.
}

“Assim, como se cuida de obrigação personalíssima, a legitimidade para figurar no pólo ativo da demanda alimentar será o filho necessitado, representado ou assistido por seu representante legal" (LOUZADA, 2008, p. 09).

Importante ressaltar que os filhos maiores de idade ou parentes acometidos de patologias físicas ou mentais impeditivas de trabalho remunerado não estão sujeitos ao fator idade, para os efeitos da aplicação das restrições acerca dos alimentos. 
Tratamos até aqui do sujeito ativo enquanto absolutamente incapaz. De forma sucinta, a incapacidade, seja ela de origem física ou mental, manterá o direito de se pleitear alimentos.

Doravante, em face da pluralidade de sujeitos que podem figurar tanto no pólo ativo quanto no pólo passivo da demanda, é possível a formação de um leque bastante abrangente de variados tipos de relações alimentícias, tratadas de forma minuciosa e em tópicos próprios por diversos doutrinadores dessa seara.

Venosa (2004, p. 399) nos ensina que:

Com relação aos filhos que atingem a maioridade, a idéia que deve preponderar é que os alimentos cessam com ela. Entende-se, porém, que a pensão poderá distender-se por mais algum tempo, até que o filho complete os estudos superiores ou profissionalizantes, com idade razoável, e possa prover a própria subsistência.

Os ascendentes maiores de 60 anos podem de igual maneira solicitar alimentos de seus descendentes capazes. O Estatuto do Idoso, Lei $n^{\circ} 10.741 / 03$, em seu art. 12, reforça tal direito, ao dizer que "a obrigação alimentar é solidária, podendo o idoso optar entre os prestadores".

Em favor do nascituro, Kich (2003, p. 13-14) defende que:

Se a gestante viesse a necessitar de cuidados médicos especiais que a impedissem de prover sua própria vida, se precisar de serviços médicos e hospitalares para resguardar a vida e ou a saúde do gerado, serviços especializados que exigem contraprestação econômica, alguém deve suprir os recursos. [...] Entre os alimentos se incluirão os gastos da gravidez e do parto, quando não estejam cobertos por outras provisões.

A guarda e a tutela são diferentes no que tange a obrigação de alimentos. Para Farias e Rosenvald (2008, p. 629), "na guarda, por não implicar suspensão ou destituição do poder familiar, impõe-se ao guardião o dever de prestar assistência material concomitantemente aos genitores". Já na tutela, "não tendo o menor [...] patrimônio que permita a sua própria manutenção, poderá cobrar do tutor ou dos parentes mais próximos".

Entre cônjuges, Louzada (2008, p. 64-65) diz que:

[...] o art. 1.702 ressalta que na separação judicial litigiosa, sendo um dos cônjuges inocente (vinculando à idéia de culpa) e desprovido de recursos, prestar-lhe-á o outro pensão alimentícia. De outra banda, o art. 1.704 e seu parágrafo único esclarecem que se um dos cônjuges separados judicialmente vier a necessitar de alimentos, não tendo sido declarado culpado (novamente a culpa como fator determinante), o outro será obrigado a prestá-lo, mas se declarado culpado (culpa 
novamente) vier a necessitar de alimentos e não tiver parentes em condições de prestá-los, nem aptidão para o trabalho, o outro cônjuge será obrigado a pagar alimentos, sendo este valor cingido ao indispensável a sua sobrevivência.

Entre companheiros, a lei assegura, conforme visto no caput do art. 1.694 do Código Civil, aos unidos estavelmente, que estejam em estado de necessidade, a possibilidade de pleitearem alimentos do seu companheiro.

Quanto aos parentes colaterais, Louzada (2008, p. 46-48) afirma:

Doutrina e jurisprudência são remansosas ao afirmarem que os tios, sobrinhos e primos do alimentando não possuem obrigação alimentar para com este. Alegam que o Código Civil em seus artigos 1.696 e 1.697 são precisos ao limitar a obrigação alimentar aos parentes colaterais até o segundo grau, ao referir-se que estão obrigados os irmãos, assim germanos como unilaterais. [...] Não nos parece crível que, ante o princípio da razoabilidade que deve consubstanciar as relações, quisesse o legislador, de forma cartesiana, afastar os tios, sobrinhos e primos do encargo alimentar, parentes esses, ratificamos, que são considerados herdeiros para efeitos sucessórios.

Com relação aos parentes por afinidade, para Dias (2009, p. 486), “dissolvido o casamento ou a união estável, possível é tanto o ex-sogro pedir alimentos ao ex-genro, como este pedir alimentos àquele. Isso tanto se a relação foi de casamento como de união estável."

Finalmente, temos a prestação de alimentos entre avós e netos, tema central do presente trabalho.

Apesar da diversidade das relações alimentícias, as razões que as embasam são as mesmas para todas: a impossibilidade de manter sua própria subsistência diante da falta de recursos materiais e a impossibilidade de gerá-los. É incabível que uma pessoa saudável e capaz venha a pleitear alimentos de outrem, pois entra em contradição de forma absoluta com o princípio jurídico universal que defende que cada indivíduo busque os próprios meios de arcar com a sua subsistência. A obrigação de prestar assistência a outra pessoa não passa de mera exceção à regra.

Entretanto, há casos em que o sujeito não consegue obter a totalidade dos recursos necessários a sua mantença, sendo este fato corriqueiro entre os idosos beneficiários de algum benefício previdenciário, que dependem única e exclusivamente dessa verba para todas as suas despesas pessoais, inclusive na área da saúde. Resta evidente que nesses casos urge a necessidade de uma suplementação aos recursos auferidos, pois o idoso já não dispõe de condições físicas laborais para obter tal complementação.

Com isso, conclui-se a parte expositiva sobre o sujeito ativo da relação alimentícia, 
abrindo-se caminho para uma análise dos três requisitos intrínsecos de identificação do sujeito passivo de tal relação.

Conceitualmente, Kich (2003, p.27) define o sujeito passivo como “[...] o contraponto de uma mesma relação jurídica, criada como dever de solidariedade familiar, vinculada à uma situação de parentesco, casamento ou convivência”.

O primeiro requisito para começar a delinear o devedor de alimentos é a capacidade civil. O Código Civil contempla dos artigos $1^{\circ}$ ao $5^{\circ}$ a definição de agente capaz e incapaz, bem como sobre a capacidade civil, alcançada a partir dos 18 anos de idade.

Já a segunda etapa consiste na análise do nexo causal, ou seja, faz-se necessário a comprovação de que o sujeito passivo da provável relação alimentícia possui parentesco com o pólo inverso ou está a ele ligado por meio do casamento ou da união estável. Para Kich, (2003, p. 28-29):

\begin{abstract}
"Está excluída, na legislação vigente, a hipótese de convivências homossexuais ou convivências concubinárias gerarem obrigação alimentícia. Tanto a Lei $n^{\circ} 8.971 / 94$ como a Lei $n^{\circ} 9.278$ insistem em união ou convivência entre homem e mulher. $\mathrm{O}$ novo Código Civil, sem revogar estas, vai se ocupar da "união estável", nos artigos 1.723 a 1.727. [...] Ficou bem claro que o legislador regulamentou, e quis efetivamente assim, a convivência entre um homem e uma mulher com o objetivo de constituir família, deixando de se manifestar sobre outros tipos de relações de convivência".
\end{abstract}

Por fim, a última exigência é aquela amplamente mencionada até então: a capacidade econômica do devedor, que deve ter rendimentos próprios, pois caso contrário, a sentença que determinar a pensão alimentícia restará inócua, sem poder indicar a fonte da verba alimentícia.

Assim, Kich (2003, p. 31) sucintamente reúne os três requisitos de forma bem simples, ao dizer:

\footnotetext{
Comprovada a necessidade do sujeito ativo e a sua incapacidade de prover os meios de subsistência, satisfaz-se um dos requisitos. Comprovado o parentesco ou o dever de assistência material do sujeito passivo, tem-se a satisfação do segundo requisito. $\mathrm{O}$ terceiro requisito reside na sua capacidade econômica, qual seja, de poder prestar os alimentos sem perder ele, seu cônjuge e filhos a quem deve assistência, a capacidade de subsistência.
}

Ora, atendidos os requisitos, qualquer pessoa poderá residir no pólo passivo da ação alimentícia, cabendo ao julgador a difícil tarefa de mensurar o quantum, já que nenhuma lei menciona valores nem fixos tampouco em termos percentuais. 


\title{
3.4 O dever de alimentar dos avós
}

$\mathrm{O}$ art. 1.696 do Código Civil dispõe que "O direito à prestação de alimentos é recíproco entre pais e filhos, e extensivo a todos os ascendentes, recaindo a obrigação nos mais próximos em grau, uns em falta de outros". Tendo em vista que o tema do presente trabalho é voltado para a relação entre avós e netos, importante se faz restringir a relação somente até segundo grau em linha reta de parentesco, haja vista serem os parentes em grau imediato mais próximo.

Há julgados no sentido de que é incabível o pedido de alimentos aos avós se um dos pais possui condições financeiras de arcar de forma digna com as despesas de seus descendentes, defendendo a tese de que "a inércia de um transmitiria ao outro genitor a totalidade da obrigação alimentar" (LOUZADA, 2008, p. 49). Nesse sentido, o Tribunal de Justiça do Rio Grande do Sul exarou decisão, cuja ementa traz-se à colação:

\begin{abstract}
ALIMENTOS. OBRIGAÇÃO AVOENGA. A OBRIGAÇÃO ALIMENTAR DOS AVÓS, POR SER SUBSIDIÁRIA E COMPLEMENTAR, SÓ SE CONFIGURA ANTE A ABSOLUTA IMPOSSIBILIDADE DE AMBOS OS GENITORES. OS AVÓS NÃO ESTÃO OBRIGADOS A PROPORCIONAR AO NETO O MESMO PADRÃO DE VIDA POR ELES DESFRUTADO, OBRIGAÇÃO QUE É, SIM, DOS GENITORES, MAS NÃO DOS PROGENITORES. PROVERAM, POR MAIORIA. (Apelação Cível No 70002611713, Sétima Câmara Cível, Tribunal de Justiça do RS, Relator: José Carlos Teixeira Giorgis, Julgado em 05/11/2001).
\end{abstract}

Contudo, há doutrinadores que divergem dessa posição, dentre eles Louzada (2008, p. 49-52), Dias (2009, p. 482-483), Farias e Rosenvald (2008, p. 627-628), pois defendem a tese de que mesmo que haja um dos genitores em condições de sustentar os filhos, ainda assim persiste a obrigação do outro genitor. Caso esse outro genitor não possua condições de amparar os filhos, por estar desempregado, por exemplo, os netos possuem o direito de pleitearem alimentos aos avós por parte desse genitor.

Dessa maneira, a obrigação alimentar dos avós caracteriza-se como subsidiária, complementar, haja vista a obrigação primeira ser dos genitores. Assim, necessário sublinhar que o neto precisa demonstrar o não-pagamento da pensão alimentícia por parte do genitor não-guardião, ou as escassas condições financeiras do mesmo. Em outras palavras, para o neto requerer diretamente alimentos em face dos avós, ele precisa adentrar em juízo contra o genitor não-guardião requerendo alimentos. Restado comprovadas as mínimas condições econômicas de tal genitor, aí sim o neto poderá promover ação de alimentos em face dos avós 
a título de complementação do valor que necessita para sua manutenção, pois caso contrário, seria impor a terceiro o pagamento de dívida alheia.

O Superior Tribunal de Justiça proferiu decisão nesse sentido, a ver:

Recurso Especial. Direito Civil. Família. Alimentos. Responsabilidade dos avós. Complementar. Reexame de provas.

- A responsabilidade dos avós de prestar alimentos aos netos não é apenas sucessiva, mas também complementar, quando demonstrada a insuficiência de recursos do genitor.

- Tendo o Tribunal de origem reconhecido a possibilidade econômica do avô e a insuficiência de recursos do genitor, inviável a modificação da conclusão do acórdão recorrido, pois implicaria em revolvimento do conjunto fático-probatório.Recurso especial não conhecido. (STJ, REsp 579385/SP, Terceira Turma, Relatora: Ministra Nancy Andrighi, julgado em 26/08/2004).

Importante se faz ressaltar que o reiterado inadimplemento da obrigação alimentícia por um dos genitores não só autoriza a cobrança dos débitos contra os avós, como também permite a propositura de ação de alimentos contra eles.

É possível que o sujeito ativo intente ação contra o pai e o avô, por exemplo, constituindo o denominado litisconsórcio passivo facultativo sucessivo. Contudo, há divergências doutrinárias em relação a tal ação. Para Louzada (2008, p. 51):

Verificamos que na prática essa forma de agir não é a melhor, pois pelo rito da Lei de Alimentos o juiz fixa desde logo o valor da pensão alimentícia e manda citar os alimentantes para audiência de conciliação, instrução e julgamento. Como em geral os filhos não têm condições de afirmar com certeza os ganhos do genitor que não detém sua guarda, o valor determinado para pagamento por parte dos avós tende a ficar muito alto, vindo a prejudicar sobremaneira aqueles que possuem obrigação subsidiária no pagamento da pensão alimentícia. Assim, entendemos que os alimentos requeridos em face dos avós devam ser postulados em ação autônoma, somente após a comprovação efetiva de que os ganhos do genitor não satisfazem as necessidades do filho.

Contudo se o autor dispõe de prova da impossibilidade do pai, Dias (2009, p. 483484) defende que:

[...] o uso da mesma demanda atende ao princípio da economia processual. $\mathrm{Na}$ instrução é que, comprovada a ausência de condições do genitor, evidenciada a impossibilidade de ele adimplir a obrigação, será reconhecida a responsabilidade dos avós. A cumulação da ação contra pais e avós tem a vantagem de assegurar a obrigação desde a data da citação.

Assim, somente nos casos em que comprovado, desde o início, a impossibilidade do pagamento pelo genitor, poder-se-á requer o pagamento da pensão alimentícia pelos avós na 
mesma ação intentada contra o genitor.

Frente ao exposto, é fácil perceber que a obrigação alimentar dos avós é excepcional, em consonância com as necessidades do alimentando e as condições financeiras do alimentante, somente se justificando quando efetivamente as necessidades dos netos não puderem ser atendidas, na sua integralidade, pelo seu genitor. Logo, a melhor condição econômica dos avós não justifica a condenação automática destes, estando submetida à prova da impossibilidade do genitor atender às necessidades do alimentando.

\subsection{O direito dos avós a alimentos}

Até este ponto, foi abordado o direito da personalidade dos netos em receber alimentos de seus avós, contudo, tal direito é recíproco e está presente tanto em sede civil (ver transcrição do artigo 1.694 do Código Civil no primeiro parágrafo do item 3.3), quanto em sede constitucional, conforme pode ser visto nos artigos abaixo transcritos:

Art. $3^{\circ}$. Constituem objetivos fundamentais da República Federativa do Brasil: I - construir uma sociedade livre, justa e solidária;

$[\ldots]$

IV - promover o bem de todos, sem preconceitos de origem, raça, sexo, cor, idade e quaisquer outras formas de discriminação.

Art. 229. Os pais têm o dever de assistir, criar e educar os filhos menores, e os filhos maiores têm o dever de ajudar e amparar os pais na velhice, carência ou enfermidade.

Art. 230. A família, a sociedade e o Estado têm o dever de amparar as pessoas idosas, assegurando sua participação na comunidade, defendendo sua dignidade e bem-estar e garantindo-lhes o direito à vida.

$\S 1^{\circ}$. Os programas de amparo aos idosos serão executados preferencialmente em seus lares.

$\S 2^{\circ}$. Aos maiores de sessenta e cinco anos é garantida a gratuidade dos transportes coletivos urbanos.

Além do mais, os artigos 11 e 12 do Estatuto do Idoso dispõem que "os alimentos serão prestados ao idoso na forma da lei civil" e que "a obrigação alimentar é solidária, podendo o idoso optar entre os prestadores".

Com o advento do Estatuto do Idoso, foi imposto o caráter solidário à obrigação alimentícia em favor do ascendente. Para Dias (2009, p. 487):

O Estatuto do Idoso veio atender ao comando constitucional que veda discriminação em razão da idade (CF 3. $\left.{ }^{\circ} \mathrm{IV}\right)$ e atribui à família, à sociedade e ao Estado o dever de 
amparo às pessoas idosas, assegurando sua participação na comunidade, defendendo sua dignidade e bem-estar e garantindo-lhes o direito à vida (CF 230). Ao operacionalizar esse direito, acaba o Estado assumindo, ainda que em caráter subsidiário e complementar, a obrigação alimentar em favor do idoso.

Estabelecido o direito dos avós a alimentos resta determinar o sujeito da obrigação. Conforme Gomes (2002, p. 436) apud Azevedo (2008, p. 44) lembra bem, a lei distribui em categorias os sujeitos da prestação alimentícia, sendo certo que:

\begin{abstract}
na primeira, encontram-se os ascendentes de primeiro grau, isto é, o pai e a mãe. Quem careça de alimentos deve reclamá-los, em primeiro lugar, aos pais. Na falta destes, a obrigação passa aos outros ascendentes, paternos ou maternos, recaindo nos mais próximos em grau, uns em falta de outros. Assim, ocupam o primeiro plano, na segunda categoria, os avós; em seguida os bisavós e assim sucessivamente. $\mathrm{Na}$ falta de ascendentes, cabe a obrigação aos descendentes, guardada a ordem da sucessão. Em primeiro lugar os filhos, em segundo os netos e assim sucessivamente. Faltando os descendentes, a obrigação incube aos irmãos, germanos ou unilaterais.
\end{abstract}

Nesse caso, considerando-se uma média de vinte anos entre uma e outra geração e uma média de vida presumida ao redor dos setenta anos, será difícil encontrar na prática ascendentes com vida ou, caso ainda estejam vivos, com capacidade contributiva em matéria de alimentos, é fatal que a obrigação recaia sobre os descendentes: filhos e netos, pela ordem.

Para os avós serem convocados a integrar o pólo passivo da ação de alimentos promovida pelos netos, necessário se faz que o genitor não-guardião se encontre em fragilidade econômica, inadimplente ou não mais presente. Da mesma forma, para os avós pleitearem alimentos aos netos, situados no segundo grau de proximidade, necessário se faz que seus filhos, descendentes mais próximos, se encontrem impossibilitados.

É importante relembrar que, além da impossibilidade dos filhos, para que os netos adentrem no pólo passivo da ação alimentícia, necessário se faz o preenchimento dos três requisitos analisados anteriormente, quais sejam: a capacidade civil, o nexo causal e a capacidade econômica. Satisfeitas tais exigências, os netos possuem o dever de prestar alimentos aos ascendentes necessitados, haja vista que

[...] não é rara a hipótese de ascendentes, já idosos, não possuírem mais condições de arcar com a sua própria mantença, seja por insuficiência de proventos (aposentadorias baixas, quando as possui), seja por doença grave e necessidade de muitos medicamentos e internamentos hospitalares (FARIAS; ROSENVALD, 2008, p. 625).

Isso posto, incube aos netos, na impossibilidade dos filhos, o dever de proporcionar 
os meios para o bem-estar biopsíquico de seus avós. Tal prestação de alimentos baseia-se não somente nos princípios da solidariedade e respeito familiar, mas também no dever de proteção que a família deve assegurar ao idoso com o intuito de defender sua dignidade e garantir-lhe o direito à vida.

\section{INADIMPLEMENTO: CABE PRISÃO CIVIL?}

A prisão civil é o meio coativo para um parente forçar o recebimento do crédito alimentar do outro parente, de acordo com os limites estabelecidos pela lei.

Mas antes de adentrar no mérito da prisão civil, é importante mencionar que o art. 17 da Lei de Alimentos estabelece outros meios de coerção para o cumprimento da prestação alimentícia, com o intuito de evitar o inadimplemento do devedor e o comprometimento da integridade do credor. A opção mais efetiva nos casos de devedores que exerçam atividade remunerada é o desconto em folha de pagamento. Caso não seja possível tal desconto, permite-se a incidência da pensão alimentícia diretamente sobre aluguéis de prédios ou de quaisquer outros rendimentos que o devedor venha a perceber.

$\mathrm{Na}$ hipótese de nenhum desses mecanismos serem eficazes, o credor pode livremente optar por duas formas executivas: ou pela penhora de bens ou pela prisão civil do devedor.

A prisão civil está assim determinada no Código de Processo Civil:

\footnotetext{
Art. 733. Na execução de sentença ou de decisão, que fixa os alimentos provisionais, o juiz mandará citar o devedor para, em 3 (três) dias, efetuar o pagamento, provar que o fez ou justificar a impossibilidade de efetuá-lo.

$\S 1^{\circ}$ Se o devedor não pagar, nem se escusar, o juiz decretar-lhe-á a prisão pelo prazo de 1 (um) a 3 (três) meses.

$\S 2^{\circ} \mathrm{O}$ cumprimento da pena não exime o devedor do pagamento das prestações vencidas e vincendas.
}

A coação pessoal do devedor solvente constante no Código de Processo Civil é uma das exceções em que a Constituição Federal admite a prisão por dívida, pois, de conformidade com o art. 5, LXVII, "não haverá prisão civil por dívida, salvo a do responsável pelo inadimplemento voluntário e inescusável de obrigação alimentícia e a do depositário infiel”.

É possível a propositura de duas execuções no mesmo procedimento, sendo uma delas a cobrança das três últimas parcelas vencidas e a outra a exigência das parcelas anteriores.

Para a aplicação da prisão civil, de acordo com Dias (2009, p. 513): 
[...] cristalizou-se o entendimento, em sede jurisprudencial, de que caberia o uso dessa via executória somente para a cobrança das três últimas prestações vencidas. A justificativa para essa restrição temporal ao uso do meio de cobrança - limitação, aliás, que não está na lei - é que a dívida alimentar acumulada por longo período perde o caráter de indispensabilidade, a garantir a sobrevivência do credor. No fim, nada mais do que uma estratégia na tentativa de dar efetividade a esse meio coercitivo, não onerando demasiadamente o devedor, de modo a inviabilizar o pagamento, em face do tamanho da dívida.

Nesse sentido, a fim de pacificar o assunto, o STJ editou a Súmula $n^{\circ} 309$ prescrevendo que "O débito alimentar que autorizar a prisão civil do alimentante é o que compreende as três prestações anteriores ao ajuizamento da execução e as que se vencerem no curso do processo".

Não há a necessidade de se esperar vencer três parcelas para se propor o rito da prisão civil, bastando o inadimplemento de uma única parcela. A cobrança de parcelas alternadas também é possível, pois muitas vezes o devedor, com a idéia de que assim estará burlando o pagamento de pensão alimentícia sem sofrer consequiências, deixa de pagar uma parcela, procede ao pagamento de outra e, logo após, volta à inadimplência.

A simples justificativa do devedor de que se encontra desempregado não o desonera do pagamento dos alimentos tampouco elide o decreto prisional, já que a vida deve prevalecer em detrimento de argumentos nada convincentes, pois o devedor poderia ter proposto ação revisional de alimentos a partir do momento em que se encontrou desamparado economicamente.

Louzada (2008, p. 176-177) é extremamente rigorosa nesse sentido, a ver:

É certo que se o devedor encontra-se desempregado, deve ter encontrado meios de se sustentar, pois ainda está vivo. De outro lado, não pode deixar aqueles que dele dependem financeiramente, lançados à própria sorte, sem ter com quem contar para sobreviver de forma digna. Ademais, se o devedor hoje se encontra desempregado, sem condições de honrar com o pensionamento alimentar anteriormente fixado, deveria ter adentrado com o feito revisional, buscando diminuir a pensão, e não deixar totalmente de pagá-la. A desídia do devedor não o protegerá judicialmente.

Filho (2007, p. 270) também é bastante rígido em relação ao descumprimento voluntário, ao dizer que "A voluntariedade prediz o descumprimento imotivado que anatemiza a omissão como indesculpável, fechando o círculo temático da execução”.

Considerando o fato de se tratar de um mecanismo de coerção, a prisão civil por inadimplemento alimentar não tem natureza punitiva. É exatamente em razão desse caráter coercitivo que não se permite a decretação de nova prisão civil pela mesma dívida. E o 
pagamento da dívida, mesmo que tenha sido efetuado por terceiros, implica a sua imediata revogação.

Contudo, o cumprimento da prisão civil não exonera o devedor do pagamento da dívida, razão pela qual o procedimento executivo continuará submetendo-se, dali em diante, à coerção patrimonial por expropriação (CPC, art. 646) ou às regras do cumprimento de sentença (CPC, art. 475-I).

Vale lembrar que cabe prisão civil tanto para a cobrança de alimentos definitivos, quanto para o cumprimento dos alimentos provisórios e provisionais, sendo vedado seu uso caso sejam estipulados via extrajudicial.

Em relação ao prazo da prisão civil, há de se pontuar controvérsia, haja vista que o caput do art. 19 da Lei de Alimentos estabelece o prazo de até 60 dias e o $\S 1^{\circ}$ do art. 733 do Código de Processo Civil, o prazo de um a três meses. Contudo, Azevedo (2008, p. 48) defende a tese de que o prazo mencionado no Código de Processo Civil é somente para alimentos provisionais e, “com relação aos alimentos definitivamente fixados por sentença ou por acordo, é de 60 dias o prazo máximo da prisão do devedor inadimplente, vem decidindo o STF e também os Tribunais dos Estados".

Ademais, a prisão civil do devedor relapso será efetuada em confinamento em cela comum, sendo executada na forma regular. Contudo, em decisão do Superior Tribunal de Justiça, foi garantida prisão domiciliar ao idoso devedor de pensão, devido à idade avançada do mesmo e variados problemas de saúde, como se vê a seguir:

HABEAS CORPUS. PRISÃO CIVIL. OBRIGAÇÃO ALIMENTÍCIA. CUMPRIMENTO DA PENA. ESTABELECIMENTO PRISIONAL. REGIME SEMI-ABERTO. LEI DE EXECUÇÕES PENAIS. INAPLICABILIDADE. PRISÃO DOMICILIAR. IDADE AVANÇADA E SAÚDE PRECÁRIA.

- Em regra, não se aplicam as normas da Lei de Execuções Penais à prisão civil, vez que possuem fundamentos e natureza jurídica diversos.

- Em homenagem às circunstâncias do caso concreto, é possível a concessão de prisão domiciliar ao devedor de pensão alimentícia. (STJ, HC 35171/RS, Terceira Turma, Relator: Ministro Humberto Gomes de Barros, julgado em 03/08/2004, DJ 23/08/2004, p. 227).

Portanto, inadimplidos os alimentos, e exauridos os outros mecanismos de compulsão, é cabível sim a prisão civil do devedor solvente, com o caráter de coerção e não de punição.

\subsection{Prisão civil dos avós}


Embora o caso mencionado acima não seja de prisão domiciliar por prisão de avós mas tendo em vista que estes geralmente são pessoas em idade avançada e com problemas de saúde, o fato narrado também lhes é possível ser imputado.

Caso lhes seja imposta a obrigação de alimentar os netos pela via judicial, aos avós também pode ser decretada a prisão civil em face do inadimplemento voluntário, contudo, a prisão civil não poder ser utilizada como meio de aniquilamento do ser humano, ultrajando seus direitos da personalidade, principalmente por se tratar de pessoas já idosas.

A Jurisprudência está mais tendente à corrente de que primeiro devem-se exaurir todos os meios compulsivos antes da decretação da prisão. Ademais, ela está adotando uma postura mais flexível nos casos de inadimplemento pelos avós, em razão dos motivos expostos até então, a ver:

AGRAVO DE INSTRUMENTO. EXECUÇÃO DE ALIMENTOS. AVÔ. DOENÇA DO ALIMENTANTE. PRISÃO CIVIL. REGIME DOMICILIAR. Embora a prisão domiciliar não encontre amparo legal, diante da excepcionalidade do caso concreto, porquanto os alimentos são exigidos do avô doente, impõe-se que se cumpra a prisão em regime domiciliar. Agravo parcialmente provido. (AI $\mathrm{N}^{\circ}$ 70023896889, Oitava Câmara Cível, Tribunal de Justiça do RS, Relator: Alzir Felippe Schmitz, Julgado em 12/06/2008).

HABEAS CORPUS. EXECUÇÃO DE ALIMENTOS. PRISÃO CIVIL. ALTERAÇÃO PARA REGIME DOMICILIAR. PACIENTE IDOSO. POSSIBILIDADE. ORDEM PARCIALMENTE CONCEDIDA. 1. Nos estreitos limites do "habeas corpus", só se admite a análise restrita do contorno da legalidade da PRISÃO ou de sua ameaça, não havendo como ser apreciada a alegação fática da impossibilidade de o paciente arcar com a obrigação alimentar que lhe foi imposta. No entanto, em se tratando de pessoas idosas, no caso o AVÔ da alimentanda, devese amenizar o nefasto efeito do cerceamento da liberdade, a fim de assegurar-lhe o mínimo de dignidade, direito fundamental a que faz jus, com absoluta prioridade, nos termos do art. $2 .^{\circ}$ da Lei n. 10.741/2003, motivo pelo qual se impõe a concessão da ordem, em parte, convolando a PRISÃO CIVIL decretada em DOMICILIAR. 2. Concede-se parcialmente a ordem. (HC No 1.0000.07.466540-7/000, Quarta Câmara Cível, Tribunal de Justiça de MG, Relator: Célio César Paduani, Julgado em 24/01/2008).

Assim, a tendência dos Tribunais é a de continuar decretando a prisão civil dos avós sempre que estes descumprirem com seu dever de alimentar os netos, embora com alguma relutância, analisando cada caso concreto e quando as circunstâncias assim o permitirem. Entretanto, eles estão mais tendentes à adoção de medidas que defendam a dignidade e bemestar dos avós, garantindo-lhes o direito à vida por meio da adoção do sistema aberto, domiciliar. 


\subsection{Prisão civil dos netos}

Conforme mencionado anteriormente, os alimentos são um direito da personalidade. Quem os presta também possui o direito de recebê-los, configurando, assim, uma reciprocidade entre o alimentante e o alimentando, conectados pelo parentesco, casamento ou união estável.

Não há dúvidas que a relação avoenga é caracterizada pelos laços sanguíneos ou afetivos, construídos com solidariedade e respeito familiar. Assim como aos avós é imputada a obrigação alimentícia aos netos, bem como a decretação da prisão civil em face do seu nãocumprimento, o mesmo pode acontecer quando há a inversão dos sujeitos da ação.

Constituída judicialmente tal obrigação, os netos sofrem todos os efeitos em casos de inadimplemento, pois eles “[...] não podem furtar-se ao amparo de seus avós, se tiverem condições econômicas de sustentá-los, em sua velhice, se necessitados” (AZEVEDO, 2008, p. $51)$.

O artigo 733 do Código de Processo Civil, já citado, não faz distinção entre as várias categorias de parentes adotadas pelo Código Civil em seus artigos 1.696 e 1.697, tratando-os de forma igual, como devedores. E de acordo com o analisado acima, cabe cobrança contra o neto devedor solvente, sendo admissível a execução mediante coação pessoal, ou seja, utilizando-se do instituto da prisão civil.

\section{O DIREITO DE VISITAÇÃO AOS NETOS EM CASO DE RUPTURA CONJUGAL}

Após essa análise em relação à prestação alimentícia entre avós e netos na impossibilidade de um dos genitores, interessante se faz analisar, também, como se regula o direito de visita entre esses dois parentes diante da ruptura conjugal. Tenha-se, de antemão, que necessário se faz a exploração do seu conceito, natureza jurídica e legislação, antes de se adentrar no mérito da visitação na relação avoenga.

A sociedade, em sua grande maioria, adota uma concepção sobre o direito de visita que não condiz com a realidade e que se refere meramente a uma autorização dada ao visitante para visitar alguém, de acordo com a sua conveniência e oportunidade.

De acordo com Boschi (2005, p. 03), “o direito de visita não é um poder conferido a alguém para dele valer-se segundo critérios subjetivos, atendendo, unicamente, a seus próprios interesses, nem se circunscreve à autonomia da vontade do visitante". Não se trata de 
um direito do visitante e, sim, um dever deste para com o visitado, que é o verdadeiro detentor do direito de receber a visitação.

No contexto de família estudado anteriormente, viu-se que os laços familiares tornam-se cada vez mais fortes e imprescindíveis ao desenvolvimento do indivíduo na sociedade, bem como que a afeição e o respeito estão assumindo papéis de vetores que indicam o dever de cooperação mútua entre os membros da família, para os fins de assistência imaterial e material.

Nesse ínterim, Boschi (2005, p. 35) conceitua o direito de visita como o "direito que têm as pessoas unidas por laços de afetividade de manter a convivência quando esta for rompida”, pois é o amor que une as pessoas e não o vínculo jurídico do parentesco. É por meio da troca de afeto e carinho que os indivíduos estabelecem seus laços sociais.

Não são os institutos do poder familiar, do parentesco e muito menos a lei que constituirão o elemento fundamental da visitação. São os vínculos afetivos existentes entre visitante e visitado que substanciam tal relação. O grau de parentesco não é responsável por fazer surgir os laços de afeição e solidariedade entre os parentes, sendo que:

[...] somente o convívio, a amizade e a relação íntima e estreita entre as partes podem suscitar o sentimento profundo, sincero, desinteressado e descompromissado, que unirá as pessoas num laço de afetividade que, ao final, poderá justificar a sua manutenção na hipótese de haver solução de continuidade. Se os parentes têm amor e dividem afeto entre si, então, eles possuem o recíproco direito de visita, ainda que não haja norma autorizando-o expressamente. [...] O que se busca no direito de visita é a permanência dos fortes vínculos de afeto positivo existente entre visitante e visitado, através da manutenção da convivência entre eles, visando fortalecer a relação como meio de garantir as necessidades emocionais das partes, evitando, por outro lado, as nefastas conseqüências oriundas da ruptura das relações de ordem sentimental. Para nós, é indiferente que essa convivência seja fruto ou não da paternidade ou da maternidade, do parentesco ou de qualquer outra relação jurídica, pois o importante é que exista entre visitante e visitado forte vínculo de afeto qualificado, ou seja, profundo, constante, saudável e necessário para o desenvolvimento integral de ambos (BOSCHI, 2005, p. 44,47).

Assim, o direito de visita é o meio utilizado para tentar manter intacta a convivência entre as partes, com a finalidade de que possam se desenvolver desfrutando da companhia um do outro e de seu afeto.

A convivência familiar torna-se, portanto, imprescindível para que se venha a implementar os variados direitos fundamentais do visitado, servindo a visita como mais um instrumento a beneficiar o seu desenvolvimento biopsicossocial. Assume, então, sob essa ótica, característica de direito da personalidade, direito fundamental de toda pessoa, baseado no princípio da dignidade da pessoa humana. 
As principais características da visitação são bem similares às dos alimentos, ou seja, é irrenunciável, recíproca, imprescritível, inalienável, e intransmissível, além de ser subordinada ao superior interesse do visitado, pois, segundo Boschi (2005, p. 84), “o visitado [...] é sempre a parte mais frágil, por isso mesmo a lei procura colocá-lo a salvo de toda forma de opressão, violência ou exploração, concedendo-lhe direitos que visam proteger sua integridade física e psíquica".

Todavia, devido aos inúmeros laços de afetividade que podem ser formados, importante se faz mencionar que é possível a combinação de inúmeras possibilidades dentro do direito de visita, mas que para o presente trabalho será analisado somente em relação aos avós e netos.

Estando os genitores vivos, porém separados em face da ruptura conjugal, uma problemática se põe no tocante à visitação dos avós, cujo filho não possui a guarda dos netos: é possível visitá-los, retirá-los da companhia do genitor-guardião e levá-los para viajar, por exemplo?

Ante todo o exposto até agora, os avós possuem o direito de visitar seus netos não só em razão do parentesco, mas principalmente em razão do vínculo de afinidade e afeto construído pelas partes. Trata-se de uma obrigação ética e moral, pois a presença dos avós na vida dos netos é muito importante para a estruturação da família, colaborando, inclusive, no processo de personificação e socialização.

Para Azevedo (2008, p. 53-54), o “[...] direito-dever da personalidade dos avós, inerentes à consangüinidade é a aptidão de cuidar dos netos e de entrevistar-se com eles. No cuidar, existe todo o empenho carinhoso de orientá-los na vida, como segundo pai e segunda mãe".

Não se pode recusar aos avós o direito de se avistarem com os netos, salvo exceções graves baseadas na característica do interesse superior do visitado. Nesse sentido, Boschi (2005, p. 165-166) informa que:

\footnotetext{
A jurisprudência, todavia, avançou muito, sendo que hoje, o direito de visita dos avós ao neto é visto como autônomo, independente do que assiste ao genitor que não convive com o filho. Admite-se, por isso, que os avós possam retirar o neto do seu domicílio, tê-lo em sua companhia, pernoitar com ele e também realizar pequenos passeios e viagens. Acreditamos que assim julgando, os tribunais estão efetivamente fazendo justiça aos avós, pois é comum e ordinário os pais deixarem os filhos com eles quando querem estar a sós, assim como é freqüente ver os netos passando as férias escolares com seus avós. [...] Pergunta-se: por que os avós, quando em visita, não poderiam retirar o neto de seu domicílio, terem-no em sua companhia e com ele viajar? A resposta é muito simples: puro capricho e intransigência de genitores egoístas e insensíveis.
} 
Assim, os efeitos do direito de visita dos avós não ficam restringidos apenas ao direito de visitar os netos, mas envolve, também, o direito de se corresponderem, de hospedar o neto e viajar com ele.

O direito de visitar os netos não encontra regulamentação na legislação pátria, sendo matéria exclusiva do Direito Natural. A jurisprudência e a doutrina têm fundamentado o direito de visita dos avós nos seguintes pressupostos: o dever de alimentar os netos, a obrigação de protegê-los contra o exercício irregular ou abusivo do poder familiar (art. 1.637, CC), o exercício obrigatório da tutela (art. 1.731, CC), o poder de requerer a interdição do neto maior incapaz (art. 1.768, CC), o exercício da guarda do neto menor (art. 1.584, § $5^{\circ}, \mathrm{CC}$ ) a vinculação parental dos avós, independente de sua vontade, ao neto adotado (art. 41, ECA).

Ademais, a interpretação sistemática e teleológica do disposto no caput do artigo 227 da Constituição da República, aliada aos pressupostos acima mencionados, acrescidos dos artigos $3^{\circ}$ a $6^{\circ}, 16$ e 19, todos do Estatuto da Criança e do Adolescente, "leva à conclusão inarredável de que os avós têm direito de conviver com seus netos, apesar da ausência, até hoje, de prescrição legal nesse sentido" (BOSCHI, 2005, p. 117-118). Nesse sentido, segue alguns julgados:

Apelação cível. Ação de regulamentação de visitas. Avó materna. Possibilidade. Direito à convivência familiar e restabelecimento dos laços familiares. Prevalência do melhor interesse da criança. Visitação assistida. Recurso provido. 1 . O direito à convivência e manutenção de laços familiares, previsto nos artigos $4^{\circ}$ e 19 da Lei $\mathrm{n}^{\circ}$ 8.069, de 13.06.1990 - Estatuto da Criança e do Adolescente, podem embasar a pretensão de avó materna para visitar sua neta. 2. É conveniente que a visita da avó materna à neta, tendo em conta que a genitora já é falecida, seja feita na presença de pessoa indicada pelo juízo diante da animosidade existente entre as duas famílias. 3. Apelação cível conhecida e provida para deferir o direito de visita da apelante à sua neta com restrições. (Apelação Cível N 1.0702.07.405527-9/001, 2ª Câmara Cível, Tribunal de Justiça de MG, Relator: Caetano Levi Lopes, Julgado em 11/05/2010)

REGULAMENTAÇÃO DE VISITAS. PEDIDO FORMULADO PELO AVÔ PATERNO, QUANDO O PAI TEVE SUSPENSO O PODER FAMILIAR. 1. É cabível a regulamentação do direito de visita pelo avô paterno, na medida em que o genitor teve suspenso o poder familiar, podendo a visitação ser aproveitada pelos tios, pois não se pode estabelecer uma barreira absoluta e intransponível do infante com a família paterna, como se a conduta do genitor fosse avalizada pelos seus familiares ou se todos tivessem o propósito de prejudicar o infante. 2. Existindo uma relação de afeto, a criança tem o direito de receber também o carinho e as atenções da sua família paterna. 3. Estando proibida qualquer forma de aproximação do genitor com o filho, a visitação ao infante pelo avô não pode ser livre, não podendo ser tratadas com a criança questões relativas ao genitor, pois está sendo submetida a tratamento psiquiátrico, precisamente para elaborar melhor as situações traumáticas que foram vivenciadas. 4. É adequada a regulamentação provisória da visitação do avô paterno ao infante de forma quinzenal, aos sábados, com duas horas de duração, devendo ser acompanhado por assistente social ou por psicólogo a ser indicado pelo juiz e remunerado pelo recorrente. Recurso provido em parte. (Agravo de 
Instrumento $\mathrm{N}^{\circ}$ 70014242176, Sétima Câmara Cível, Tribunal de Justiça do RS, Relator: Sérgio Fernando de Vasconcellos Chaves, Julgado em 03/05/2006)

Por fim, por se tratar de um intercâmbio familiar, os netos também possuem o direito, bem como o dever de cuidar de seus avós, não só propiciando alimentos, mas sim estabelecendo uma convivência movida pelo afeto e afinidade, assistindo-os e amparando-os, em todos os momentos.

\section{CONCLUSÃO}

O Direito de Família, como ramo do Direito Civil que regula as relações familiares, tem incorporado as inovações surgidas no campo da Responsabilidade Jurídica, trazendo à tona um novo enfoque às Responsabilidades das Famílias.

No ordenamento jurídico brasileiro, princípios garantidores da dignidade da pessoa humana estabelecem que o indivíduo tem o direito à solidariedade social para que não padeça à míngua.

Esta solidariedade social é formada por ciclos sociais de proximidade com o indivíduo, sendo que o ciclo social mais próximo dele é a família, onde existem camadas que partem dos mais próximos aos mais remotos graus de parentesco.

Diante da Responsabilidade Familiar, concretizada no direito positivo, família hoje não é mais aquela formada apenas por pai, mãe e filhos, mas é compreendida por todos aqueles que possuem laços sanguíneos e de afetividade.

Portanto, a prestação de alimentos ao familiar carente, no caso do presente trabalho, avós ou netos, tornou-se uma obrigação jurídica de assistência, decorrente da lei, em consonância com as necessidades do alimentando e as condições financeiras do alimentante.

E, numa época em que tanto se fala em obrigação alimentar, é importante lembrar que, embora não contemplado de modo expresso na lei, o direito de visitas entre avós e netos encontra guarida nos princípios do direito natural, pois visando preservar os laços de afeição que os unem, interferem diretamente na dignidade humana dos envolvidos, não podendo ser proibidos ou restritos sem motivo relevante.

\section{REFERÊNCIAS}


AZEVEDO, Álvaro Villaça. Direitos e deveres dos avós: alimentos e visitação. Revista do Advogado AASP, São Paulo, v. 28, n. 98, p. 39/58, jul. 2008.

BOSCHI, Fabio Bauab. Direito de Visita. São Paulo: Saraiva, 2005.

DIAS, Maria Berenice. Manual de Direito das Famílias. 5. ed, São Paulo: Revista dos Tribunais, 2009.

FARIAS, Cristiano Chaves de; ROSENVALD, Nelson. Direito das Famílias - de acordo com a Lei no 11.340/06 - Lei Maria da Penha e com a Lei no 11.441/07 - Lei da Separação, Divórcio e Inventário Extrajudiciais. Rio de Janeiro: Editora Lumen Juris, 2008.

FILHO, Bertoldo Mateus de Oliveira. Alimentos e Investigação de Paternidade. 4. ed, Belo Horizonte: Del Rey, 2007.

GONÇALVES, Carlos Roberto. Direito Civil Brasileiro: Direito de Família. 3. ed, v.6, São Paulo: Saraiva, 2007.

Direito de Família (Sinopses Jurídicas). 9. ed, v.2, São Paulo: Saraiva, 2003.

KICH, Bruno Canísio. Direito de Alimentos e Assistência Familiar. Campinas: Agá Juris, 2003.

LISBOA, Roberto Senise. Manual de Direito Civil. 3. ed, v.5, São Paulo: RT, 2004.

LOUZADA, Ana Maria Gonçalvez. Alimentos - Doutrina e Jurisprudência. Belo Horizonte: Del Rey, 2008.

VENOSA, Sílvio de Salvo. Direito Civil: Direito de Família. 6. ed, v.6, São Paulo: Atlas, 2006. 